\title{
Formation of transparent exopolymer particles, TEP, from dissolved precursor material
}

\author{
Uta Passow* \\ Marine Science Institute, University of California, Santa Barbara, California 93106, USA
}

\begin{abstract}
Transparent exopolymer particles (TEP) form from polysaccharides released by many phytoplankton species, but this process by which dissolved organic matter becomes particulate is poorly understood. Here, the abiotic formation of TEP from precursors $<0.2 \mu \mathrm{m}$ and the minimum molecular weight (MW) of TEP-precursors were studied. In most samples TEP formed from material $<0.2 \mu \mathrm{m}$ (polycarbonate membrane filters, Poretics) when exposed to laminar shear in Couette flocculators. This result was unexpected as no TEP formed from material $<0.45 \mu \mathrm{m}$ (polycap capsules, Whatman) due to surface coagulation onto bubbles (Zhou et al. 1998; Limnol Oceanogr 43:1860-1871). Some TEP-precursors were able to pass through dialysis bags with a nominal pore size of $8 \mathrm{kDa}$ (natural cellulose, Spektrum), although their $M W$ is presumably 2 orders of magnitude larger, suggesting that TEP-precursors can be fibrillar. It is suggested that treshly released precursors are fibrillar and that these fibrillar precursors form larger colloids and eventually TEP within hours to days after their release.
\end{abstract}

KEY WORDS: TEP · Particle formation - Exudation

\section{INTRODUCTION}

Dissolved organic carbon (DOC) increases during or shortly after blooms due to phytoplankton excretions (Kepkay et al. 1993, Niven et al. 1995). The fate of this newly generated carbon depends largely on how it is partitioned among the different carbon pools, because processes controlling the cycling of carbon in the ocean differ between DOC, colloidal organic carbon (COC) and particulate organic carbon (POC) (Gustafsson \& Geschwend 1997). Solutes and colloids do not sink, but are transported passively with the ambient water, without substantial removal by settling. However, residence times of colloids in seawater are similar to those of small particles (Moran \& Büsseler 1992, Huh \& Prahl 1995) and, in contrast to solutes, colloids can coagulate and form aggregates (Wells \& Goldberg 1993, Kepkay 1994) which eventually sediment or are grazed. Thus, if the cycling of carbon in the ocean is to be understood, mechanisms and rates of transforma-

•E-mail: passow@lifesci.ucsb.edu tions between the different carbon pools must be understood.

The recent discovery of the high abundance $\left(10^{6}\right.$ to $10^{8} \mathrm{I}^{-1}$ ) of previously unconsidered particles called TEP (transparent exopolymer particles, Alldredge et al. 1993) further heightens the need to understand and quantify particle production in the ocean. TEP, which consist of acidic polysaccharides, are filterable onto $0.4 \mu \mathrm{m}$ filters and can be up to several $100 \mu \mathrm{m}$ in length. TEP form from polysaccharides released by phytoplankton (Passow \& Alldredge 1994, 1995a, Passow et al. 1994). The formation of TEP may potentially represent a pathway by which DOC released by phytoplankton is removed from the euphotic zone, because, as an essential component of marine snow (Alldredge et al. 1993, Logan et al. 1995), TEP can sediment rapidly (Passow et al. 1994).

Transformations between the different fractions of organic carbon may be mediated by biotic or by abiotic processes. Biotic transformations include the formation of POC from DOC via bacterial utilization (Chrost \& Faust 1983, Sundh 1989, Sell \& Overbeck 1992, Alber \& Valiela 1994) or via grazer feeding on colloidal mat- 
ter (Sherr 1988, Flood et al. 1992, Tranvik et al. 1993). Abiotically, particles can be generated from non-filterable material by adsorption to hard surfaces, like carbonate, clays or detrital matter (Otsuki \& Wetzel 1973, Avnimelech et al. 1982, Jensen \& Søndergaard 1982, Fattom \& Shilo 1984, Bar-Or \& Shilo 1987, Bender et al. 1994), or by surface coagulation onto rising bubbles (Baylor \& Sutcliffe 1963, Riley 1963, Sutcliffe et al. 1963, Johnson 1975, Johnson \& Cooke 1980). However, it is believed that colloids between 0.2 and $1.2 \mu \mathrm{m}$ are needed for abiotic particle formation as no particulate matter is formed by bubbling material $<0.2 \mu \mathrm{m}$ (Johnson et al. 1986, Kepkay \& Johnson 1989)

TEP can also form by 2 abiotic processes: adsorption onto surfaces (Passow \& Wassmann 1994) and bubble scavenging (Mopper et al 1995, Zhou et al. 1998). Precursors of TEP appear to also be $>0.45 \mu \mathrm{m}$, as in previous studies very little TEP formed from substances $<0.45 \mu \mathrm{m}$ (Polycap capsules, Whatman) via bubble absorption (Zhou et al. 1998). However, TEP formed on particles (siliceous fibers) from mucus generated from Phaeacystis spp. colonies by pressure filtration through $0.2 \mu \mathrm{m}$ (membrane) and enrichment onto $500 \mathrm{Da}$ (Passow \& Wassmann 1994).

Experiments presented in this paper were conducted to determine if TEP can form from non-filterable precursors at natural concentrations in the absence of particles or bubbles and if TEP can form from precursors $<0.4 \mu \mathrm{m}$ in size. Another goal was to determine the minimum size of precursors from which TEP can form abiotically. Finally, experiments were conducted with samples representing different plankton assemblages under various growth conditions to assess if characteristics of abiotic TEP formation varied as a function of the phytoplankton releasing the precursors.

\section{METHODS}

The abiotic formation of TEP from precursors $<0.2 \mu \mathrm{m}$ (polycarbonate membrane, Poretics) was investigated by exposing precursors to laminar shear in Couette flocculators (flocculator experiments). The minimum size of precursors able to form TEP was studied in dialysis bag experiments. A total of 14 flocculator and 11 dialysis bag experiments were conducted using water from various sampling sites reflecting different ecological conditions. Between 1 and 4 dialysis barg experiments arcnminanied most flocrulator experiments. Table 1 gives an overview of the experiments conducted.

Flocculator experiments. Flocculator experiments were primarily designed to study the abiotic formation of TEP from material $<0.2 \mu \mathrm{m}$ in the absence of bubbles or particles. TEP are, by definition, particles retained by $0.4 \mu \mathrm{m}$ filters (polycarbonate membrane, Poretics), whereas TEP-precursors include all substances which pass through $0.4 \mu \mathrm{m}$ filters, but will potentially form TEP. In flocculator experiments the formation of TEP was studied from precursors $<0.2 \mu \mathrm{m}$ (polycarbonate membrane, Poretics), to be conservative. A second goal was to use TEP production as an estimate of relative amounts of precursor concentration. Precursor concentration can currently not be measured directly, as TEP-precursors appear to be a chemically complex group of acidic polysaccharides which can form particles (TEP). The formation of TEP under constant conditions should represent a relative estimate of precursor concentration.

A small (volume: $160 \mathrm{ml}$ ) Couette flocculator was used for the 5 experiments conducted in June 1995 and a larger Couette flocculator (volume: $1600 \mathrm{ml}$ ) was used for experiments conducted during the mesocosm study in November 1995 and the study with Phaeocystis spp. in April 1996. A Couette flocculator, which consists of a fixed inner and a rotating outer cylinder, provides a quantifiable 2-dimensional laminar shear in the annular space between the cylinders (Duuren 1968). Expts F1 to F5 (Table 1) were rotated at a shear of $15.2 \mathrm{~s}^{-1}$, whereas the larger flocculator generated a shear of $24.9 \mathrm{~s}^{-1}$. In all experiments samples were pre-filtered through $0.2 \mu \mathrm{m}$ filters (polycarbonate membrane, Poretics) and incubated in the flocculator for $24 \mathrm{~h}$. When pre-filtering water for flocculator experiments, care was taken to avoid collecting TEP in the filtrate by keeping the filtration pressure below $150 \mathrm{~mm} \mathrm{Hg}$ and by not letting the filter become dry. The concentration of TEP was determined initially in the $0.2 \mu \mathrm{m}$ filtered water and again after $24 \mathrm{~h}$ of incubation. Flocculators and flasks were rinsed well with ethanol, and then 3 times with distilled water to avoid bacterial contamination of $0.2 \mu \mathrm{m}$ filtered seawater. Production of TEP in flocculators was calculated by subtracting the initial concentration of TEP in flocculators from the final concentration.

Dialysis bag experiments. Dialysis bag experiments were primarily designed to estimate the minimum molecular weight (MW) of TEP-precursors. For each experiment seawater was incubated within dialysis bags of varying MW cut-off, and the formation of TEP monitored both within bags and in the water surrounding the bags. It was hypothesized that TEP-precursors generated by the assemblage of organisms growing within the dialysis bags would potentially diffuse through bags and that TEP would form abiotically in the pre-filtered, autoclaved seawater (PASW) surrounding the bag Total production of TEP, which should reflect ambient precursor concentration + newly released precursors, was calculated by adding the amount of TEP formed in PASW and within bags at the end of the experiment and subtracting the initial concentrations. 
Table 1. Flocculator and dialysis bag experiments conducted at each of the sampling dates (MW: molecular weight cut-off of dialysis bags, $n$ : number of replicate dialysis bag experiments)

\begin{tabular}{|c|c|c|c|c|c|c|c|}
\hline \multirow[t]{2}{*}{ Sample description } & \multirow{2}{*}{$\begin{array}{l}\text { Collection date } \\
\qquad(\mathrm{mo} / \mathrm{d} / \mathrm{yr})\end{array}$} & \multicolumn{2}{|c|}{$\begin{array}{c}\text { Flocculator } \\
\text { experiments }\end{array}$} & \multicolumn{4}{|c|}{ Dialysis bag experiments } \\
\hline & & Expt no. & $\begin{array}{l}\text { Shear } \\
\left(s^{-1}\right)\end{array}$ & Expt no. & $\begin{array}{l}\text { Duration } \\
\text { (h) }\end{array}$ & $\begin{array}{c}\mathrm{MW} \\
(\mathrm{KDa})\end{array}$ & $\mathrm{n}$ \\
\hline \multicolumn{8}{|c|}{ Diatom bloom in Santa Barbara Channel } \\
\hline Diatom bloom at peak & $6 / 17 / 95$ & $\mathrm{~F} 1$ & 15.2 & D1a & 72 & 50 & 4 \\
\hline $\begin{array}{l}\text { Diatom bloom at peak } \\
\text { fraction }>5 \mu \mathrm{m}\end{array}$ & $6 / 17 / 95$ & & & $\mathrm{D} 1 \mathrm{~b}$ & 72 & 504 & \\
\hline Diatom bloom, clouding & $6 / 18 / 95$ & F2 & 15.2 & D2 & 72 & 50 & 3 \\
\hline Diatom bloom, flocked & $6 / 19 / 95$ & F3 & 15.2 & & & & \\
\hline \multicolumn{8}{|c|}{ Diatom bloom grown in a mesocosm } \\
\hline Lag-phase & $10 / 28 / 95$ & $F 8^{b}$ & 24.9 & $D 4$ & 49 & $6-8$ & 3 \\
\hline Growth phase & $10 / 29 / 95$ & F9 & 24.9 & & & & \\
\hline Growth phase & $10 / 30 / 95$ & F10 & 24.9 & D5 & 48 & $6-8$ & 3 \\
\hline Growth phase & $10 / 31 / 95$ & F11 & 24.9 & D6 & 48 & $6-8$ & 3 \\
\hline Late growth phase & $11 / 1 / 95$ & F12 & 24.9 & & & & \\
\hline Senescence & $11 / 2 / 95$ & F13 & 24.9 & & & & \\
\hline Senescence & $11 / 3 / 95$ & $F 14$ & 24.9 & D7 & 72 & $6-8$ & 3 \\
\hline \multicolumn{8}{|l|}{ Non-diatom systems } \\
\hline Growing Phaeocystis spp. & $\begin{array}{l}4 / 18 / 96 \text { or } \\
4 / 25 / 96^{d}\end{array}$ & F15 & 24.9 & D8a & 60 & 25 & 3 \\
\hline $\begin{array}{l}\text { Growing Phaeocystis spp. } \\
\text { fraction }<200 \mu \mathrm{m}\end{array}$ & $4 / 18 / 96$ & & & $\mathrm{D} 8 \mathrm{~b}$ & 60 & 25 & 3 \\
\hline Growing Phaeocystis spp. & $4 / 18 / 96$ & & & D9a & 60 & 2 & 3 \\
\hline $\begin{array}{l}\text { Growing Phaeocystis spp. } \\
\text { fraction }<200 \mu \mathrm{m}\end{array}$ & $4 / 18 / 96$ & & & D9b & 60 & 2 & 3 \\
\hline Phaeocystis spp aged $5 \mathrm{~d}$ & $4 / 18 / 96$ & $F 16$ & 24.9 & D10 & 60 & 25 & 3 \\
\hline Phaeocystis spp aged $5 \mathrm{~d}$ & $4 / 18 / 96$ & & & D11 & 60 & 2 & 3 \\
\hline Deep water (chl a-poor) & $7 / 12 / 95$ & $\mathrm{~F} 4$ & 15.2 & & & & \\
\hline Nanoflagellate bloom & $6 / 21 / 95$ & F5 & 15.2 & D3 & 44 & $6-8$ & 3 \\
\hline \multicolumn{8}{|c|}{$\begin{array}{l}{ }^{2} \text { D8 and D9 were conducted with growing Phaeocystis spp. collected on } 18 \text { April 1996, whereas F15 was conducted wit } \\
\text { growing Phaeocystis spp. collected on } 25 \text { April } 1996 \\
\text { b Expts F6 and F7 do not exist }\end{array}$} \\
\hline
\end{tabular}

For each dialysis bag experiment, between 9 and 27 clear $280 \mathrm{ml}$ bottles were rotated on rolling tables at in situ temperature and low light $\left(20\right.$ to $\left.60 \mu \mathrm{E} \mathrm{m}^{-2} \mathrm{~s}^{-1}\right)$ for 44 to $72 \mathrm{~h}$ (Table 1 ). Each bottle contained a dialysis bag (Spectra/Por 7 from Spectrum, made of natural cellulose) filled with 50 to $100 \mathrm{ml}$ of fresh, raw seawater. Dialysis bags with a MW cut-off between 2 and $50 \mathrm{KDa}$ were used (Table 1). Dialysis bags were suspended in pre-filtered $(0.2 \mu \mathrm{m})$, autoclaved seawater (PASW) collected from below $100 \mathrm{~m}$. The sterile PASW contained no TEP and little or no TEP-precursors. The continuous rotation on rolling tables ensured mixing during the experiment and facilitated formation of TEP as rolling tables generate turbulent shear (Jackson 1994). Concentrations of TEP were determined initially and at the end both within the bags and in the PASW surrounding the bags. Each experiment consisted of 3 to 4 replicate bottles plus 2 to 4 control bottles. Empty dialysis bags suspended in PASW were used as con- trols. All containers were either autoclaved or washed with ethanol and rinsed 3 times with sterile water to avoid contamination and growth of bacteria in the water surrounding the dialysis bags.

Additional dialysis bag experiments (D1b, D8b, D9b) were conducted to test which size fraction of the phytoplankton community was responsible for the production of TEP-precursors. In experiment D1b, particles $<5 \mu \mathrm{m}$ were removed from the sample (particles retained on $5 \mu \mathrm{m}$ mesh were resuspended in $0.2 \mu \mathrm{m}$ filtered seawater), incubating predominately diatoms. In experiments D8b and D9b Phaeocystis spp. colonies were excluded by filtration through a $200 \mu \mathrm{m}$ mesh (Table 1). Single Phaeocystis spp. cells, which were not excluded, did not form colonies during the experiment.

Apparent mass transfer coefficients, which can be viewed as the inverse of the resistance against precursors passing through bags, were estimated for each experiment because they allow direct comparisons 
between experiments, even when experimental conditions and type of bag vary. Theoretically, the amount of TEP formed in PASW depended on the diffusion of precursors through bags. Besides being a function of the MW of precursors in relation to the MW cut-off of bags, the rate of diffusion depended upon the duration of the experiment, the surface area of the bag and the concentration gradient of the precursors. Mass transfer coefficients normalize for these latter variables. However, as I could not measure precursor concentrations directly, the production of TEP was used as a relative estimate of ambient precursor concentration. Apparent mass transfer coefficients were thus estimated from TEP concentrations using the following relationship (Cussler 1984): the flux through dialysis bags ( $F_{\text {TEP; }} \mu \mathrm{g}$ xan. eq. $\mathrm{m}^{-2} \mathrm{~s}^{-1}$ ) equals the concentration gradient times the apparent mass transfer coefficient $\left(k ; \mathrm{m} \mathrm{s}^{-1}\right)$. Since TEP concentration is used as a measure for the precursor concentration:

$$
F_{\text {TEP }}=k \cdot\left[T E P_{i}-T_{E P} P_{\text {PASW }}\right]
$$

$\mathrm{TEP}_{\mathrm{i}}$ and TEPPASW ( $\mu \mathrm{g}$ xan. eq. $\mathrm{m}^{-3}$ ) represent the concentration of TEP inside and outside of bags respectively at the end of the experiment.

Sample types. Diatom blooms: Some flocculator (F1 to F3) and dialysis bag (D1 and D2) experiments were conducted with water collected at the chlorophyll (chl a) maximum (at 10 to $15 \mathrm{~m}$ ) during the flocculation of a diatom bloom in the Santa Barbara Channel (SBC) in summer 1995. Flocculator (F8 to F14) and dialysis bag (D4 to D7) experiments were also conducted with samples collected during the growth and decline of a diatom bloom grown in a 1400 l mesocosm in fall 1995 To initiate the bloom, raw seawater from a depth of $15 \mathrm{~m}$ was inoculated with $50 \mathrm{l}$ of surface water from the $\mathrm{SBC}$ and nutrients were added $\left(\mathrm{NO}_{3}+\mathrm{NO}_{2}=60 \mu \mathrm{M}\right.$, $\left.\mathrm{SiO}_{4}=50 \mu \mathrm{M}, \mathrm{PO}_{4}=5 \mu \mathrm{M}\right)$. The temperature in the mesocosm was held constant at $12^{\circ} \mathrm{C}$, a $14: 10 \mathrm{~h}$ light:dark regime was imposed and the mesocosm was mixed by a propeller rotating slowly near the bottom (for a detailed description of the mesocosm see Alldredge et al. 1995).

Non-diatom phytoplankton: For comparison, experiments were also conducted with samples stemming from blooms dominated by Phaeocystis spp. or nanoflagellates. Expts F15, D8 and D9 were run with water collected during the growth phase of a bloom dominated by colonial Phaeocystis pouchetti which developed in Balsfjord Svartnes, Norway $\left(69^{\circ} 21.8^{\prime} \mathrm{N}\right.$, $19^{\circ} 06.5^{\prime} \mathrm{E}$ ) in April 1996. An aliquot of the water sampled on 18 April was aged at in situ temperature $\left(2^{\circ} \mathrm{C}\right)$ in the dark for $5 \mathrm{~d}$ and then used in lieu of a senescent Phaeocystis spp. population from the field for Expts F16, D10 and D11. Expts F5 and D3 were conducted with samples from a summer bloom of autotrophic nanoflagellates collected on 21 June in the SBC. One flocculator experiment (F4) was conducted with water from below the euphotic zone $(150 \mathrm{~m})$.

Chemical analysis. TEP was determined following the colorimetric method (Passow and Alldredge 1995b). Briefly, TEP were filtered onto $0.4 \mu \mathrm{m}$ filters, stained with an Alcian Blue solution and soaked in $80 \%$ sulfuric acid. The dye redissolves in sulfuric acid and its concentration may be determined spectrophotometrically at $787 \mathrm{~nm}$. Blanks (empty, but stained filters) were subtracted and absorption calibrated with gum xanthan. TEP concentrations are expressed as gum xanthan equivalent. This unit does not reflect the absolute weight of TEP and potentially the equivalent amounts of TEP generated under different conditions could result in varying degrees of staining. Standard deviations between the 4 replicate measurements conducted for each sample were usually below $5 \%$, in a few cases between 5 and $10 \%$. Chl a was determined in sample water using 2 replicate $20 \mathrm{ml}$ samples filtered onto GF/F filters and analyzed following standard fluorometric methods (Parsons et al. 1984) using a Turner Model 111 fluorometer.

\section{RESULTS}

\section{Diatom blooms}

\section{Flocculator experiments}

Initial concentrations of TEP in $0.2 \mu \mathrm{m}$ pre-filtered seawater were always near the detection limit of the method $\left(<30 \mu \mathrm{g}\right.$ xan eq. $\left.\mathrm{l}^{-1}\right)$, but after subjecting the samples to shear generated in a flocculator for $24 \mathrm{~h}$ TEP was always present. Production of TEP during the diatom bloom in the SBC was highest on the first sampling day, 17 June (F1). About half as much TEP was generated in the sample collected $1 \mathrm{~d}$ later (F2) and comparably little TEP the following day (F3) (Fig. 1a). During the growth period of the mesocosm bloom (F9 to F13), TEP production in flocculators was relatively constant, and lower than during the lag phase (F8, Fig. 1b). During experiments conducted at the end of the mesocosm bloom (F14), however, TEP production in the flocculators increased appreciably.

\section{Dialysis bag experiments}

TEP could only form in PASW of dialysis bag experiments if precursors were (1) present within bags and (2) small enough to diffuse through bags. TEP was generated abundantly within dialysis bags of all exper- 

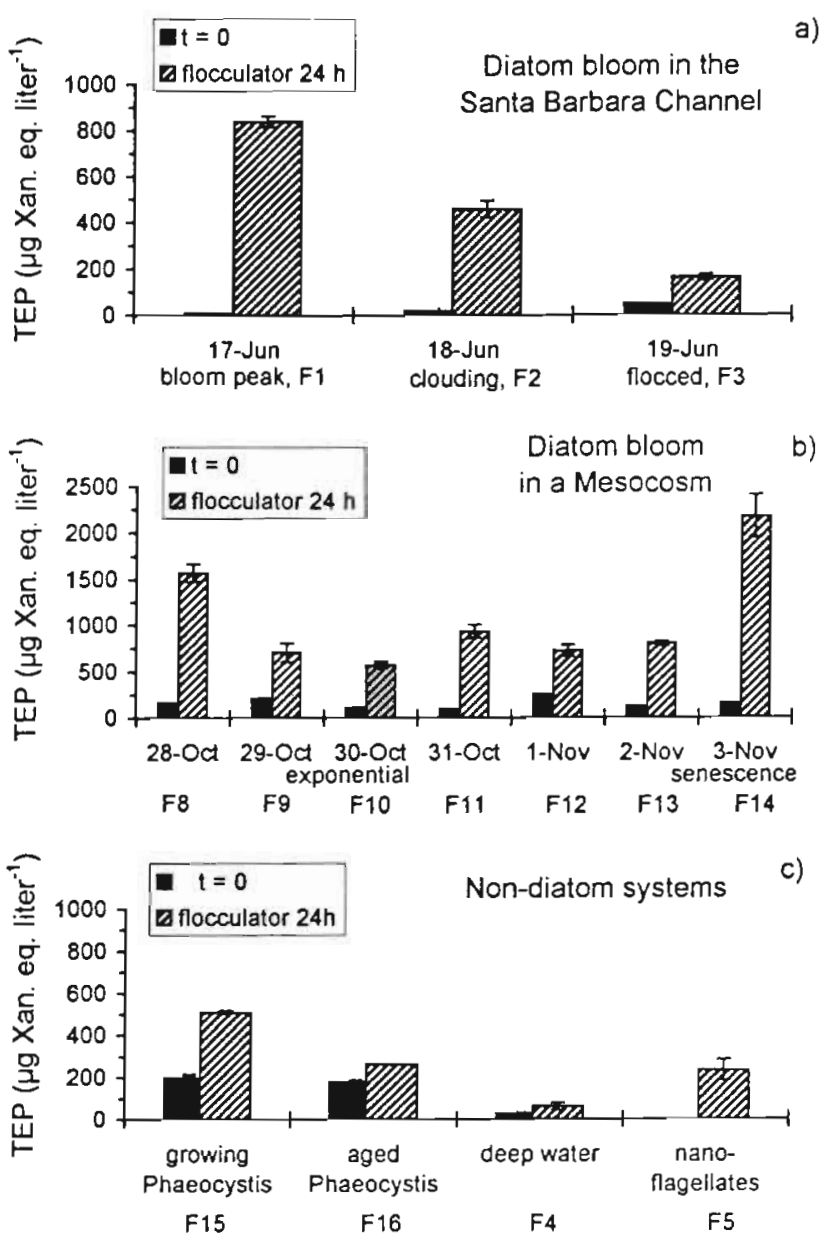

Fig. 1. Results of flocculator experiments. (a) diatom bloom in the Santa Barbara Channel, (b) diatom bloom in a mesocosm and (c) non-diatom systems. In each experiment concentration of TEP was measured in $0.2 \mu \mathrm{m}$ filtered seawater initially $(t=0)$ and after $24 \mathrm{~h}$ incubation in a flocculator (flocculator $24 \mathrm{~h}$ ). Error bars are standard deviations of replicate TEP measurements (analytical replicates). Note change of scale

iments conducted with diatoms, showing that precursors were always present in the water during diatom blooms. TEP were not generated in PASW of controls, implying that (1) PASW was free of TEP and their precursors, (2) the bags did not generate any TEP-like artifacts and (3) no TEP-generating organisms (bacteria for example) were present. The absence of TEP in PASW of controls confirms that TEP in PASW of experiments must have formed abiotically from precursors passing through the bags.

TEP was formed in PASW during experiments with the diatom bloom from the SBC (D1 and D2, Fig. 2a,b) indicating that precursors passed through the $50 \mathrm{kDa}$ bags. The amount of TEP formed in PASW was lower during Expt D2 sampled $1 \mathrm{~d}$ after Expt D1, but only a small amount of TEP formed within bags and the apparent transfer coefficient in Expt D2 was an order of magnitude higher compared to that in Expt D1 (Table 2). The higher apparent transfer coefficient in D2 suggests that precursors passed through bags more easily compared to those in Expt D1. Results of Expt D1b, where only the size fraction $>5 \mu \mathrm{m}$ was incubated, were the same as those of Expt D1a, where the whole water sample was incubated, indicating that the size fraction $>5 \mu \mathrm{m}$, which consisted predominantly of diatoms, was primarily responsible for the release of TEP-precursors.

In experiments conducted at the beginning of the mesocosm diatom bloom (D4), the concentration of TEP in PASW was not significantly different from controls, suggesting that precursors did not pass through $8 \mathrm{kDa}$ bags (Fig. 2c). However, the formation of TEP in PASW later in the bloom (D5 and D6) implies that TEPprecursors passed through $8 \mathrm{kDa}$ bags at this time (Fig. 2d), which is confirmed by the increase of the apparent transfer coefficients by an order of magnitude (Table 2). During the experiment conducted at the end of the mesocosm bloom (D7), the median concentration of TEP in PASW was only marginally higher than that of controls (Fig. 2e), resulting in a very small apparent transfer coefficient (Table 2). The small apparent transfer coefficient suggests that precursors did not pass through $8 \mathrm{kDa}$ bags at the end of the bloom.

\section{Non-diatom blooms}

\section{Flocculator experiments}

After subjecting the samples to shear some TEP had formed in the experiments with the growing Phaeocystis spp. (F15), but TEP production in the experiments conducted with the aging Phaeocystis spp. (F16) was negligible (Fig. 1C). TEP formed in the sample collected during a nanoflagellate bloom (F5, Fig. 1C), but almost no TEP was generated in the water collected from below the euphotic zone (F4). These results suggest that concentrations of TEP-precursors $<0.2 \mu \mathrm{m}$ in the deep water sample and in the sample of the aging Phaeocystis spp. were insufficient to form TEP. Precursor concentrations in water of the growing Phaeocystis spp. and the nanoflagellate bloom, however, were high enough for TEP to form abundantly.

\section{Dialysis bag experiments}

No TEP formed within bags of experiments conducted with the growing Phaeocystis spp. (D8 and D9) (Table 2), indicating that precursor concentrations 

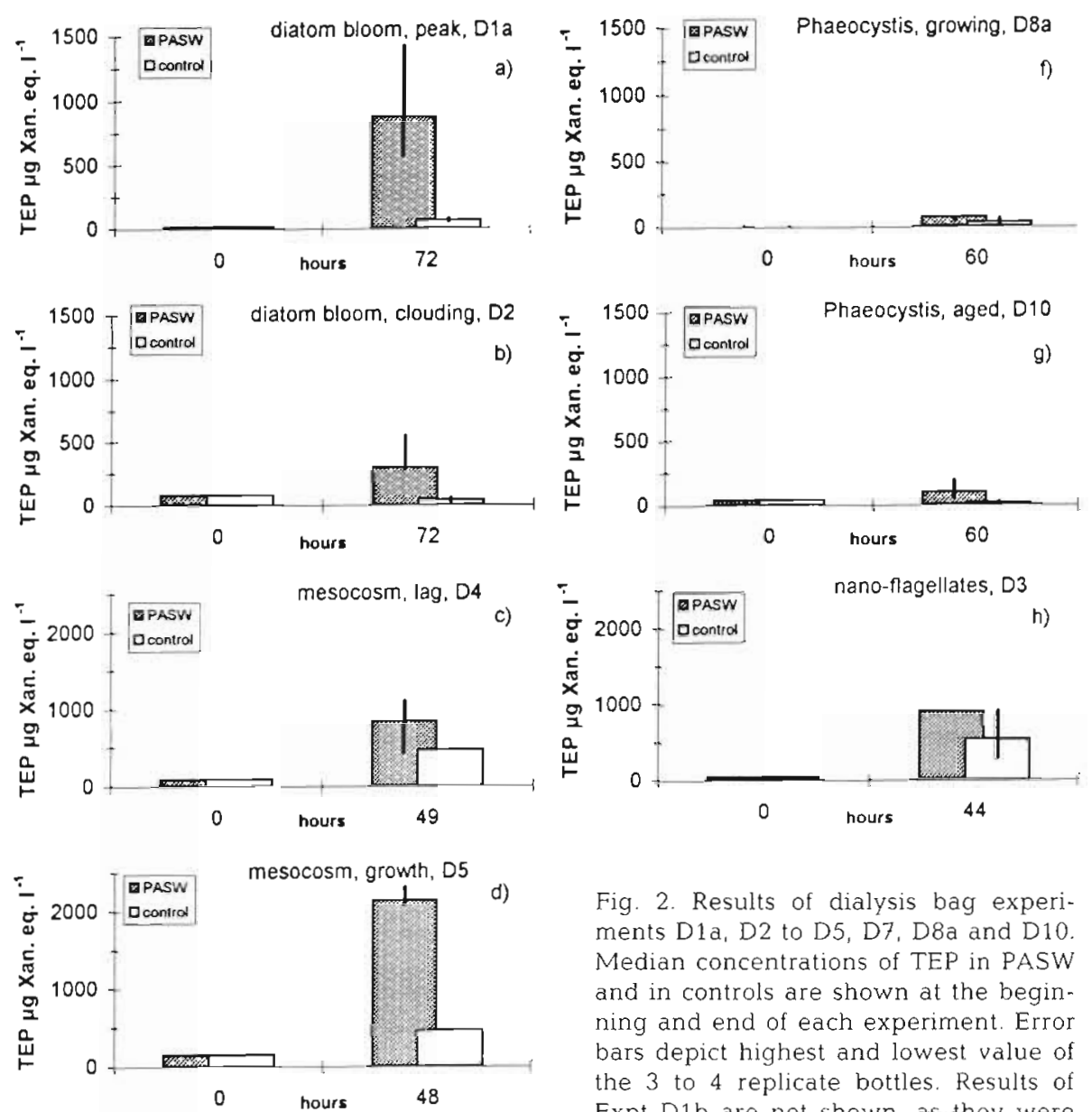

Fig. 2. Results of dialysis bag experiments D1a, D2 to D5, D7, D8a and D10. Median concentrations of TEP in PASW and in controls are shown at the beginning and end of each experiment. Error bars depict highest and lowest value of the 3 to 4 replicate bottles. Results of Expt D1b are not shown, as they were very similar to those of Expt D1a. Results of experiments D5 and D6 were smilar.

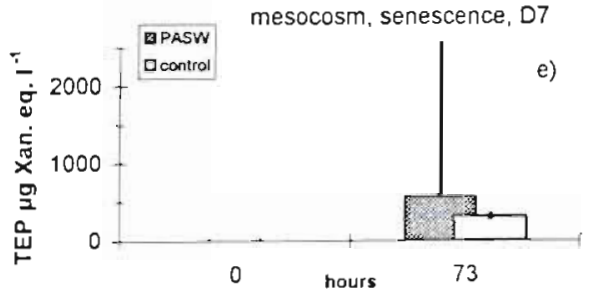
Results of Expt D8a were similar to those of Expts D8b, D9a and D9b and results of Expt D10 were similar to those of Expt D11 Only Expts D8a and D10 are shown. Note scale change for experiments with mesocosm bloom

were low in samples of the growing Phaeocystis spp. Consequently no TEP appeared in the PASW of Expts D8 and D9 (Fig. 2f). Expts D8a and D8b as well as Expts D9a and D9b were similar, emphasizing that neither Phaeocystis spp. colonies (fraction $>200 \mu \mathrm{m}$, D8a and D9a) nor organisms in the smaller size fraction (D8b and D9b) released significant amounts of TEPprecursors during the experiments. Also, precursor concentrations at the time of sampling were low. Although TEP were formed abundantly within bags during experiments with aged Phaeocystis spp. colonies (D10 and D11, Table 21, TEP was negligible in PASW whether the $25 \mathrm{kDa}$ (D10) (Fig. 2g) or the $2 \mathrm{kDa}$ (D11) dialysis bags were used, implying that precur-

sors were $>25 \mathrm{kDa}$ in samples with aged Phaeocystis spp. Small apparent transfer coefficients confirm that precursors generated by the aging Phaeocystis spp. could not pass through the bags (Table 2).

Significant amounts of TEP formed in PASW in the experiments with the nanoflagellate bloom, but because some of the controls were high, this result is ambigunus (Fig. $2 \mathrm{~h}$ ).

\section{Minimum size of precursors}

Actual MW cut-off of ultra-filters may differ from the nominal value given by the vendor and depend, 
Table 2. Results of dialysis bag experiments ( $\mu \mathrm{g}$ xan. eq. $\mathrm{l}^{-1}=\mu \mathrm{g}$ xanthan equivalent $\mathrm{l}^{-1}$ ). nv: no value

\begin{tabular}{|c|c|c|c|c|c|c|c|}
\hline \multirow[t]{2}{*}{ Expt } & \multirow[t]{2}{*}{ Description } & \multirow{2}{*}{$\begin{array}{l}\text { MW of bags } \\
\text { (kDa) }\end{array}$} & \multirow{2}{*}{$\begin{array}{c}\text { Chl a } \\
\text { within bags } \\
\left(\mu \mathrm{g} \mathrm{l}^{-1}\right)\end{array}$} & \multicolumn{2}{|c|}{ TEP within bags } & \multirow{2}{*}{$\begin{array}{c}\text { TEP in PASW, } \\
t_{\text {end }} \\
\left(\mu \mathrm{g} \text { xan. eq. } l^{-1}\right)\end{array}$} & \multirow{2}{*}{$\begin{array}{c}\text { Transfer } \\
\text { coefficient, } k \\
\left(10^{-9} \mathrm{~m} \mathrm{~s}^{-t}\right)\end{array}$} \\
\hline & & & & $\begin{array}{c}t_{\text {initual }} \\
\left.\text { ( } \mu \text { g xan. eq. } l^{-1}\right)\end{array}$ & $\begin{array}{c}t_{\text {end }} \\
\left(\mu \mathrm{g} x a n \text { eq. } \mathrm{l}^{-1}\right)\end{array}$ & & \\
\hline \multicolumn{8}{|c|}{ Diatom bloom in Santa Barbara Channel } \\
\hline $\mathrm{D} 1 \mathrm{a}$ & Bloom peak & 50 & 3.2 & 122 & 6309 & 958 & $42^{\mathrm{a}}$ \\
\hline D2 & Clouding & 50 & 1.9 & 245 & 405 & 347 & $282^{b}$ \\
\hline \multicolumn{8}{|c|}{ Diatom bloom grown in a mesocosm } \\
\hline D4 & Lag-phase & 8 & 1.7 & 298 & 5941 & 792 & 4 \\
\hline D5 & Growth phase & 8 & 13.9 & 516 & 4643 & 2185 & 40 \\
\hline D6 & Growth phase & 8 & 37.2 & 935 & 4704 & 1810 & 30 \\
\hline $\mathrm{D} 7$ & Senescence & 8 & 220.0 & 1552 & 9238 & 1276 & 1 \\
\hline \multicolumn{8}{|c|}{ Non-diatom systems } \\
\hline D8a & Growing Phaeocystis spp. & p. 25 & 2.8 & 770 & 833 & 63 & 3 \\
\hline D9a & Growing Phaeocystis spp. & p. 2 & 2.8 & 770 & 843 & 78 & 4 \\
\hline D10 & Phaeocystis spp. aged $5 \mathrm{~d}$ & d 25 & nv & 560 & 2488 & 115 & 4 \\
\hline D11 & Phaeocystis spp. aged $5 \mathrm{~d}$ & d 2 & nv & 560 & 2177 & 115 & 4 \\
\hline D3 & Nanoflagellates & 8 & 2.0 & 140 & 871 & 902 & 108 \\
\hline
\end{tabular}

among other factors, on the concentration of colloids (Büsseler et al. 1996, Gustafsson et al. 1996). Here, estimates of the transfer coefficients were made without direct measurements of the precursor concentration gradient and retention characteristics of our system were not calibrated. However, estimated apparent transfer coefficients remained similar for at least $96 \mathrm{~h}$ (Table 2) during the time series Expt D2 (sampled after 48,72 and $96 \mathrm{~h}$ ). This suggests that differences between apparent transfer coefficients estimated from the dialysis experiments reflect real differences in the ability of precursors to diffuse through bags. If minimum sizes of precursors were the same in all samples, differences in apparent transfer coefficients should be a function of the pore-size of bags. During the experiments presented here, apparent transfer coefficients varied by 2 orders of magnitude between 1 and $300 \times$ $10^{-9} \mathrm{~m} \mathrm{~s}^{-1}$, but no relationship between MW cut-off of bags and apparent transfer coefficients was observed. For example, apparent transfer coefficients were very low $\left(<5 \times 10^{-9} \mathrm{~m} \mathrm{~s}^{-1}\right)$ in Expts D4 and D7, whereas apparent transfer coefficients were high $\left(>100 \times 10^{-9} \mathrm{~m}\right.$ $\mathrm{s}^{-1}$ ) in Expt D3, although $8 \mathrm{kDa}$ bags were used in all 3 experiments (Table 2). Or, apparent transfer coefficients were similar in experiments D2, D5 and D6, although the MW cut-off of bags was $50 \mathrm{kDa}$ for Expt D2 and 6 to $8 \mathrm{kDa}$ for Expts D5 and D6 (Table 2). Apparent transfer coefficients appeared to depend more on the characteristics of the sample than on the MW of bags.

\section{TEP production in relation to environmental conditions}

Similarly, the production of TEP also appeared to be a function of the characteristics of the samples: TEP was generated in most experiments, but the amount of TEP formed varied widely between experiments. The following section will relate the TEP production in flocculator and dialysis bag experiments to the environmental conditions of the respective samples.

TEP was formed abundantly both in flocculator and dialysis bag experiments on the first day of experiments (F1 and D1) in the SBC, when the diatom bloom reached peak concentration. The bloom, which was dominated by Chaetoceros spp., had not begun to aggregate (no macroscopic aggregates were visible to divers), but on the following day, 18 June, aggregation began (clouding), and large sinking flocs were observed, although the surrounding seawater was still green from freely suspended cells. Chlorophyll concentrations in the water decreased from 3.2 to $1.9 \mu \mathrm{g} \mathrm{l}^{-1}$ (Table 2, Fig. 3a), presumably due to sedimentation of large diatom aggregates. Production of TEP both in flocculator and in dialysis bag experiments also decreased appreciably at this time (Fig. 3b), although ambient concentrations of TEP did not decrease, but remained approximately constant at around $80 \mu \mathrm{g}$ xan. eq. $\mathrm{l}^{-1}$ (Fig. $3 \mathrm{a}$ ). The following day (19 June) the bloom was fully aggregated and TEP 


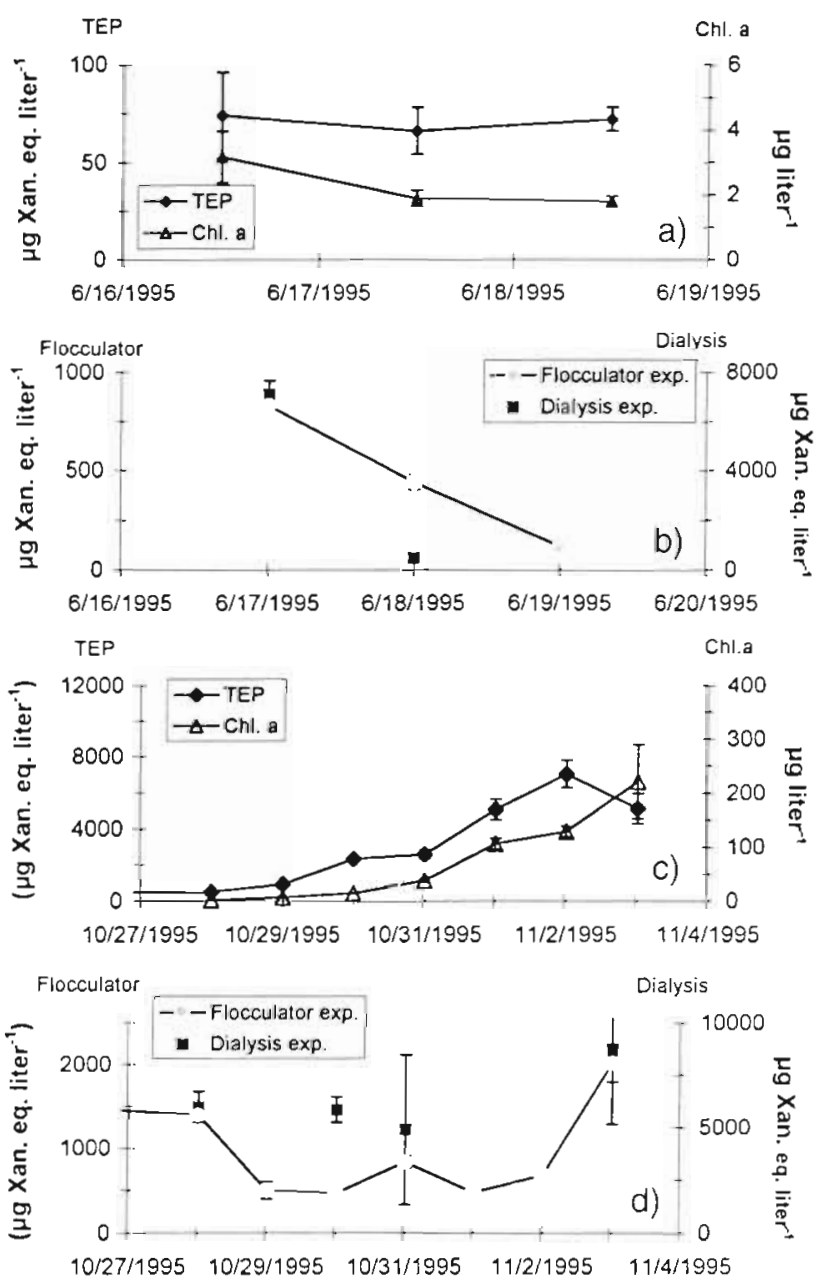

Fig. 3. $(a, c)$ Ambient TEP and chl a concentration and $(b, d)$ production of TEP in flocculator experiments (estimate of precursor concentration) and in dialysis experiments (relative estimate of precursor concentration + release rate) during $(a, b)$ the diatom bloom in the Santa Barbara Channel and $(c, d)$ the mesocosm bloom

production in flocculator experiments decreased even further (Fig 3b).

The mesocosm bloom, which was also dominated by Chaetoceros spp., entered its exponential growth after 29 October, when both primary production and chl a concentration increased rapidly (Fig. 3c) until nutrients became limiting. Nutrients were depleted on 2 November (author's unpubl. results) and the bloom entered senescence, which was also reflected in a dristic increase of phacopigment concentration (12 to $146 \mu \mathrm{g} \mathrm{I}^{-1}$ ) between 2 and 3 November. TEP concentrations, which had increased exponentially during the growth phase, dropped of 1 at senescence (Fig. 3c). TEP production in flocculator experiments decreased at the onsel of growth, remained low during growth and increased at senescence, whereas production of TEP in dialysis bag experiments remained constant at the beginning of the growth period and increased slightly at senescence (Fig. 3d). No large diatom aggregates formed to terminate the bloom, but during late senescence a few small micro-aggregates consisting of detrital matter and bacteria were observed.

No measurable TEP formed during dialysis experiments conducted with material collected on 18 April (D8 and D9), when the colony density of the growing Phaeocystis spp. bloom reached about 25 colonies $\mathrm{ml}^{-1}$ (chl d: $2.8 \mathrm{\mu g}^{-1} \mathrm{j}$. This contradicts results of the respective flocculator experiment F15, where TEP was formed. Expt F15 was conducted on 25 April, when the colony density had reached about 50 colonies $\mathrm{ml}^{-1}$. Samples for both experiments were, however, taken a week apart and apparently reflected differences (physiological or environmental) that were not observed. TEP was generated within bags of dialysis experiments with senescent Phaeocystis spp. colonies, although no TEP formed in the respective flocculator experiment, suggesting that TEP-precursors must have been $>0.2 \mu \mathrm{m}$ in samples of the aging Phaeocystis spp. colonies. TEP may have been formed directly from pieces of disintegrating colonies (Passow \& Wassmann 1994, Hong et al. 1997) rather than from dissolved precursors.

\section{DISCUSSION}

Results clearly indicate that TEP can form abiotically from dissolved precursors small enough to pass through $0.2 \mu \mathrm{m}$ filters (polycarbonate membrane). The production of TEP from material $<0.2 \mu \mathrm{m}$ was surprising, as experiments on the formation of TEP by bubble scavenging had suggested that TEP-precursors were larger than $0.45 \mu \mathrm{m}$ (Polycap capsules) (Zhou et al. 1998). Results presented here show not only that TEP can form from material $<0.2 \mu \mathrm{m}$, but that this happened in the absence of bubbles or particles. Instead, precursors were subjected to laminar shear in flocculator experiments and turbulent shear on rolling tables (Jackson 1994) Using shear to generate POC from DOC is a new and, it appears, very efficient method to generate TEP and presumably other organic particles. The highest concentration of TEP generated in flocculator experiments from material $<0.2 \mu \mathrm{m}$, was about 2 orders of magnitude larger ( $>2000 \mu$ gan. eq. $\mathrm{I}^{-1}$ ) than the highest concentration of TEP generated by bubbling material $<10 \mathrm{~mm}$ ! 30 ! 10 xan. eq. $\mathrm{l}^{-1}$. normalized to 15.3 I of water bubbled at optimized extraction efficiency; Zhou et a1. 1998). However, a direct comparison between both methods is impossible, as scavenging efficiency by bubbing depends on bubble concentration and size distribution which can not be compared directly to shear rate. 
TEP consist of surface active, acidic polysaccharides enriched in covalently bound sulfate (Passow \& Alldredge 1995b, Zhou et al. 1998). Polysaccharides are large molecules with a MW of several $100 \mathrm{~s}$ to $1000 \mathrm{~s}$ of $\mathrm{kDa}$. Microbe-produced polysaccharides, which appear similar to TEP under the microscope, such as alginate or xanthan (Passow \& Alldredge 1995b), for example, are polydisperse with molecular weights of 200 to 2000 and 100 to $2500 \mathrm{kDa}$, respectively (Buffle et al. 1998). TEP-precursors were thus initially not expected to pass through $50 \mathrm{kDa}$ bags. However, in some dialysis bag experiments TEP was formed from precursors passing through dialysis bags with a nominal pore size of 6 to $8 \mathrm{kDa}$. Presumably, this large discrepancy cannot be solely explained by artifacts (fouling or aging of membranes) or by the assumption that the nominal MW cut-off of dialysis bags as specified by the producers is too low (see Büsseler et al. 1996, Gustafsson et al. 1996). However, polymers which are freshly released by diatoms exist as long fibrils with a diameter of about 2 to $10 \mathrm{kDa}$ (Leppard 1995, Leppard et al. 1997). It appears that because of their fibrillar nature these polymers can pass through an ultra-filter with a poresize of about $10 \mathrm{kDa}$, although their $\mathrm{MW}$ is 2 orders of magnitude higher (Santschi et al. 1998).

The abiotic formation of large colloids or particles from small fibrillar polymers involves their assembly to nanogels, which then form larger colloids by annealing and aggregation (Chin et al. 1998). Fibrillar polymers may also aggregate with inorganic colloids by bridging, forming loose aggregations (Buffle \& Leppard 1995). Thus, it may be assumed that freshly released fibrillar TEP-precursors form larger colloids and eventually TEP as they age. If, because of their fibrillar nature, freshly released TEP-precursors are able to pass through $8 \mathrm{kDa}$ filters, whereas larger colloids formed from these fibrillar precursors cannot, the fraction of precursors able to pass through $8 \mathrm{kDa}$ filters is primarily a function of the age of precursors and of the conditions influencing polymer assembly and aggregation.

Theoretical considerations suggest that in aquatic systems free macromolecules disappear quickly (within hours to days), whereas particles in the size range of TEP are more stable (Buffle \& Leppard 1995). As TEPprecursors are highly surface active (Mopper et al. 1995), the formation of larger non-fibrillar colloids and particles should be rapid. Gelation theory suggests that after large colloids and particles are removed by filtration a new equilibrium between polymers and large colloids will be reached within hours to days (Chin et al. 1998). The fact that comparably little TEP is generated by bubbling water with low algal activity (pre-bloom or post-bloom) compared with bubbling water with high algal activity (Zhou et al. 1998) suggests that turn-over times of TEP-precursors in situ are also in the range of hours to days. If freshly released precursors aggregate up the size scale to form larger colloids and ultimately TEP within hours to days, the precursor concentration in the water would be expected to mirror the ecological growth situation of phytoplankton fairly closely, without much lag-time. High concentrations of TEP and their precursors should thus be associated with phytoplankton blooms releasing these substances.

Results of experiments presented here are consistent with such an interpretation. By combining data from flocculator and dialysis bag experiments, changes in the release rate of precursors were estimated and compared to apparent transfer coefficients. Increases in the release rate should occur simultaneously with increases in apparent transfer coefficients, because a larger fraction of freshly released precursors implies a larger fraction of precursors able to pass through bags, which results in a large apparent transfer coefficient. A comparison between production of TEP in flocculator and dialysis bag experiments allowed estimates of relative changes in the release rate of precursors, because TEP production in flocculator experiments depended on the ambient concentration of precursors $<0.2 \mu \mathrm{m}$, whereas the total production of TEP in dialysis experiments (in PASW + within bags) depended on the concentration plus the release of precursors.

The steeper slope of the decrease in total TEP production during dialysis experiments compared to flocculator experiments during the early aggregation of the diatom bloom in SBC (Fig. 3b) indicates that release rate of precursors decreased during the aggregation phase. As predicted, the apparent transfer coefficients decreased simultaneously. During the growth phase of the mesocosm bloom, the large relative difference between the production of TEP in dialysis and flocculator experiments compared to the lag-phase or senescence suggests that during growth the release rate was higher (Fig. 3d), which was also mirrored by the apparent transfer coefficients.

Precursor concentration, as estimated from TEP production in flocculator experiments, also varied over the course of the blooms. Precursor concentrations which were high during the peak of the diatom bloom in the SBC decreased as the bloom began aggregating (Fig. 3b), suggesting rapid turnover of precursors to TEP. Ambient concentration of TEP, however, did not increase simultaneously. The decrease in chl a concentration and the observation that aggregates were sinking imply that an appreciable amount of TEP sedimented, probably as marine snow, since TEP are an essential part of diatom aggregates (Alldredge et al. 1993, Logan et al. 1995, Passow \& Alldredge 1995a). During the aggregation phase of this bloom, loss of TEP due to sinking must have balanced the production of TEP from precursors. 
Although the release rate of precursors increased at the onset of growth of the mesocosm bloom, and remained high, no accumulation of precursors was observed. The ambient precursor concentration decreased and remained low (Fig. 3d). The simultaneous exponential increase of TEP during growth (Fig. 3c) suggests the rapid formation of TEP from freshly released precursors. Low precursor concentration and a rapid turnover to TEP in the mesocosm experiment may have been facilitated by the mixing of the mesocosm $(70 \mathrm{~cm}$ propeller stirred at $2.6 \mathrm{rpm}$, energy dissipation rate $=0.0137 \mathrm{~cm}^{2} \mathrm{~s}^{-3}$ )

Results of low precursor concentration in deep water fit observations that fibrillar colloids, which are very abundant in productive surface water, are much rarer in deep water (Santschi et al. 1998) The low concentration of precursors in deeper waters also confirms that TEP-precursors are generated primarily by phytoplankton and that the turnover times of precursors to TEP are rapid. Although, phytoplankton release a wide variety of organic substances (Decho 1990), whose chemical composition varies between species (Allan et al. 1972, Myklestad 1974, Painter 1983) and physiological stage (Myklestad et al. 1972, 1989, Myklestad 1995), TEP-precursors appear more homogeneous. The monomer composition of TEP remained fairly constant, despite changes in algae composition, and all TEP analyzed to date (sampled from 4 different sites and ecological situations) has consisted of strongly sulfated polysaccharides enriched in desoxysugars and galactose (Mopper et al. 1995. Zhou et al 1998). The high concentration of covalently bonded sulfates may explain why TEP themselves are frequently found in deeper waters (Passow \& Alldredge 1994), as preliminary data suggest that hydrolysis rates of polysaccharides high in sulfates are much slower compared to other polysaccharides (Arnosti 1999). TEP and their precursors appear to be a chemically distinct group of polysaccharides whose production and standing stocks are uncoupled from bulk carbohydrates (Mopper et al. 1995).

Acknowledgements. Paul Wassmann and Marit Reigstad made the work in Norway possible, Alice Alldredge, Kumiko Azetsu-Scott and 2 especially helpful reviewers are gratefully acknowledged for comments on an earlier version of the paper. The work was funded by the NSF grant OCE94-00698, a Marshall Funds Followship for Norway and by the Deutsche Forschungsgemeinschaft

\section{LITERATURE CITED}

Alber M. Valiela I (1994) Production of microbial organic aggregates from macrophyte-derived dissolved organic material. Limnol Oceanogr 39:37-50
Allan GG, Lewin J, Johnson PG (1972) Marine polymers: IV. Diatom polysaccharides. Bot Mar XV:102-108

Alldredge AL, Passow U, Logan B (1993) The existence, abundance, and significance of large transparent exopolymer particles in the ocean. Deep-Sea Res I 40:1131-1140

Alldredge AL, Gotschalk C, Passow U, Riebesell U (1995) Mass aggregation of diatom blooms: insights from a mesocosm study. Deep-Sea Res II 42:9-28

Arnosti C (1999) Characterization of extracellular enzymatic hydroly'sis rates and substrate specific biofilms. In: Limnology and oceanography: navigating into the next century, February 1999, Santa Fe, NM. The American Society of Limnology and Oceanography, Santa Fe, p 16 (Abstract)

Avnimelech Y, Troeger BW, Reed IW (1982) Mutual flocculation of algae and clay: evidence and implications. Science 216:63-65

Bar-Or Y, Shilo M (1987) Characterization of macromolecular flocculants produced by Phormidium sp. strain J-1 and by Anabaenopsis circularis PCC 6720. Appl Environ Microbiol 53:2226-2230

Baylor ER, Sutcliffe WH (1963) Dissolved organic matter in seawater as a source of particulate food. Limnol Oceanogr 8:369-371

Bender J, Rodriguez-Eaton S, Ekanemesang UM, Phillips P (1994) Characterization of metal-binding bioflocculants produced by the cyanobacterial component of mixed microbial mats. Appl Environ Microbiol 60:2311-2315

Buffle J, Leppard GG (1995) Characterization of aquatic colloids and macromolecules. 2. Key role of physical structures on analytical results. Environ Sci Tech 29:2176-2184

Buffle J, Wilkinson KJ, Stoll S, Filelld M, Zhang J (1998) A generalized description of aquatic colloidal interactions: the three-colloidal component approach. Environ Sci Technol 32:2887-2899

Busseler, KO, Bauer JE, Chen RF, Eglinton TI, Gustafsson O, Landing W, Mopper K, Moran SB, Santschi PH, Vernonclark R, Wells M. (1996) An intercomparision of crossflow filtration techniques used for sampling marine colloids: overvew and organic carbon results. Mar Chem 55:1-31

Chin WC, Orelland MW, Verdugo P (1998) Spontaneous assembly of marine dissolved organic matter into polymer gels. Nature 391:568-571

Chróst RH, Faust MA (1983) Organic carbon release by phytoplankton: its composition and utulization by bacterioplankton. J Plankton Res 5:447-493

Cussler El (1984) Diffusion: mass transfer in fluid systems. Cambridge University Press, Cambridge

Decho AW (1990) Microbial exopolymer secretions in ocean environments: their role in food webs and marine processes. Mar Biol Annu Rev 28:73-153

Duuren FA (1968) Defined velocity gradient model flocculator. J Sanit Eng Div Proc Am Soc Civil Eng 94 (SA) 4:671-682

Fattom A, Shilo M (1984) Phormidium J-1 bioflocculant: production and activity. Arch Microbiol 139:421-426

Flood PR, Deibel D, Morris CC (1992) Filtration of colloidal melanin from seawater by planktonic tunicates. Nature 335:630-632

Gustafsson $\ddot{O}$. Geschwend PM (1997) Aquatic colloids: concepts, definitions and current challenges. Limnol Oceanजित $: 22.513-528$

Gustafsson O, Büsseler KO, Geschwend PM (1996) On the integrity of cross-flow filtration for collecting marine organic colloids. Mar Chem 55:93-111

Hong Y, Smith WO Jr. White AM (1997) Studies on transparent exopolymer particles (TEP) produced in the Ross Sea (Anlarctica) by Phaeocystis Antarctica (Prymnesiophyceae). I Phycol $33: 368-376$ 
Huh CA, Prahl FG (1995) Role of colloids in upper ocean biogeochemistry in the northeast Pacific Ocean from ${ }^{238} \mathrm{U}-{ }^{234} \mathrm{Th}$ disequilibria. Limnol Oceanogr 40:528-532

Jackson GA (1994) Particle trajectories in a rotating cylinder: implications for aggregation incubations. Deep-Sea Res I 41:429-437

Jensen LM, Sondergaard M (1982) Abiotic formation of particles from extracellular organic carbon released by phyto. plankton. PSZN I: Mar Ecol 8:47-54

Johnson BD (1975) Non-living organic particle formation from bubble dissolution. Limnol Oceanogr 21:444-446

Johnson BD, Cooke RC (1980) Organic particle and aggregate formation resulting from the dissolution of bubbles in sea water. Limnol Oceanogr 25:653-661

Johnson BD, Zhou X, Wangersky PJ (1986) Surface coagulation in seawater. Neth J Sea Res 20:201-210

Kepkay PE (1994) Particle aggregation and the biological reactivity of colloids. Mar Ecol Prog Ser 109:293-304

Kepkay PE, Johnson BD (1989) Coagulation on bubbles allows the microbial respiration of oceanic dissolved organic carbon. Nature 385:63-65

Kepkay PE, Niven SE, Milligan TG (1993) Low molecular weight and colloidal DOC production during a phytoplankton bloom. Mar Ecol Prog Ser 100:233-244

Leppard GG (1995) The characterization of algal and microbial mucilage and their aggregates in aquatic ecosystems Sci Total Environ 165:103-131

Leppard GG, West M, Flannigan DT, Carson J, Lott JNA (1997) A classification scheme for marine organic colloids in the Adriatic Sea: colloid speciation by transmission electron microscopy. Can J Fish Aquat Sci 54:2334-2349

Logan BE, Passow U, Alldredge AL, Grossart HP, Simon M (1995) Rapid formation and sedimentation of large aggregates is predictable from coagulation rates (half-lives) of transparent exopolymer particles (TEP). Deep-Sea Res II 42:203-214

Mopper K, Zhou J, Ramana KS, Passow U, Dam HG, Drapeau DT (1995) Role of surface-active carbohydrates in the flocculation of a diatom bloom in a mesocosm. Deep-Sea Res II $42: 47-74$

Moran SB, Büsseler KO (1992) Short residence time of colloids in the upper ocean estimated from ${ }^{238} \mathrm{U}-{ }^{234} \mathrm{Th}$ disequilibria. Nature 359:221-223

Myklestad S (1974) Production of carbohydrates by marine planktonic diatoms: I. Comparison of nine different species in culture. J Exp Mar Biol Ecol 15:261-274

Myklestad S (1995) Release of extracellular products by phytoplankton with special emphasis on polysaccharides. Sci Total Environ 165:155-164

Myklestad S, Haug A. Larsen B (1972) Production of carbohydrates by the marine diatom Chaetoceros affinis var. willei (Gran) Hustedt II. Preliminary investigation of the extracellular polysaccharide. J Exp Mar Biol Ecol 9:137-144

Myklestad S, Holm-Hansen O, Varum KM, Volcani BE (1989) Rate of release of extracellular amino acids and carbohydrates from the marine diatom Chaetoceros affinis. J Plankton Res 11:763-773

Editorial responsibility: Otto Kinne (Editor), Oldendorf/Luhe, Germany
Niven SEH, Kepkay PE, Boraie A (1995) Colloidal organic carbon and colloidal ${ }^{234} \mathrm{Th}$ dynamics during a coastal phytoplankton bloom. Deep-Sea Res II 42:257-272

Otsuki A, Wetzel RG (1973) Interaction of yellow organic acids with calcium carbonate in freshwater. Limnol Oceanogr 18:490-493

Painter TJ (1983) Algal polysaccharides. In: Aspinall GO (ed) The polysaccharides. Academic Press, New York, p $196-275$

Parsons TR, Maita Y, Lalli CM (1984) A manual for chemical and biological methods for seawater analysis. Pergamon Press, New York

Passow U, Alldredge AL (1994) Distribution, size and bacterial colonization of transparent exopolymer particles (TEP) in the ocean. Mar Ecol Prog Ser 113:185-198

Passow U, Alldredge AL (1995a) Mass aggregation of a diatom bloom in a mesocosm: the role of TEP. Deep-Sea Res II 42:99-11.0

Passow U, Alldredge AL (1995b) A dye binding assay for the spectrophotometric measurement of transparent exopolymer particles (TEP). Limnol Oceanogr 40:1326-1335

Passow U, Wassmann P (1994) On the trophic fate of Phaeocystis pouchetii (Hariot): IV. The formation of marine snow by P. pouchetti. Mar Ecol Prog Ser 104:153-161Passow U, Alldredge $\mathrm{AL}$, Logan $\mathrm{B}$ (1994) The role of particulate carbohydrate exudates in the flocculation of diatom blooms. Deep-Sea Res 41:335-357

Riley GA (1963) Organic aggregates in seawater and the dynamics of their formation and utilization. Limnol Oceanogr 8:372-381

Santschi PH, Balnois E, Wilkinson KJ, Zhang J, Buffle J (1998) Fibrillar polysaccharides in marine macromolecular organic matter as imaged by atomic force microscopy and transmission microscopy. Limnol Oceanogr 43: $896-908$

Sell AF, Overbeck J (1992) Exudates: phytoplankton-bacterioplankton interaction in Plußsee. J Plankton Res 14: $1199-1292$

Sherr EB (1988) Direct use of high molecular weight polysaccharide by heterotrophic flagellates. Nature 335: $348-351$

Sundh I (1989) Characterization of phytoplankton extracellular products (PDOC) and their subsequent uptake by heterotrophic organisms in a mesotrophic forest lake. J Plankton Res 11:463-486

Sutcliffe WH, Baylor ER, Menzel DW (1963) Sea surface chemistry and Langmuir circulation. Deep-Sea Res 10: 233-243

Tranvik LJ, Sherr EB, Sherr BF (1993) Uptake and utilization of 'colloidal DOM' by heterotrophic flagellates in sea water. Mar Ecol Prog Ser 92:301-309

Wells ML, Goldberg ED (1993) Colloid aggregation in seawater. Mar Chem 41:353-358

Zhou J, Mopper K, Passow U (1998) The role of surface-active carbohydrates in the formation of transparent exopolymer particles (TEP) by bubble adsorption of seawater. Limnol Oceanogr 43:1860-1871

Submitted: May 10, 1999; Accepted: August 2, 1999

Proofs received from author(s): January 7, 2000 